\title{
Implementation of International Standards for Determining an Efficient Civil Law Remedy by a National Court
}

\author{
Andrii V. Potapenko ${ }^{1, *}$, Svitlana A. Pylypenko ${ }^{2}$, Vitalii M. Korolenko ${ }^{1}$ and Iryna S. Melnyk ${ }^{3}$ \\ ${ }^{1}$ Department of the Jurisdiction Forms of Legal Protection of Subjects of Private Law, the Judiciary and Legal \\ Proceedings, Academician F.H. Burchak Scientific and Research Institute of Private Law and \\ Entrepreneurship of the National Academy of Legal Sciences of Ukraine, Kyiv, Ukraine \\ ${ }^{2}$ Department of Civil Law Disciplines, National Academy of Internal Affairs, Kyiv, Ukraine \\ ${ }^{3}$ Department of Notary, Enforcement, and Advocacy, Prosecutor's Office, Judiciary Taras Shevchenko \\ National University of Kyiv, Kyiv, Ukraine
}

\begin{abstract}
The article is devoted to studying the effectiveness of protection of violated, unrecognised or disputed rights, freedoms or interests of individuals, rights and interests of legal entities, the interests of the state in civil proceedings. The purpose of the article is to study how to implement international standards for determining an efficient civil law remedy by the court: (based on the case-law of the European Court of Human Rights and national case law). Clarification of the essence of novels of substantive and procedural law in determining the court's effective way to protect private law as the final judicial procedure of the right to judicial protection was by comparative law, methods of analysis, modelling and synthesis with the implementation of related elements of classical methods of protection and reception of the best acquisitions of legal systems of foreign countries, norms of the Convention of the case-law of the European Court of Human Rights (from now on - ECtHR). The dialectical method of cognition and the qualitative empirical method were also the main ones, by means of which the legal nature of the category "efficiency" and "determination by the court of an effective way of protection of private law and interest" were clarified.
\end{abstract}

Keywords: Litigation, the remedy of private law, international standards, ECtHR, ECHR.

\section{INTRODUCTION}

Optimising the efficiency of the judiciary is one of the main tasks in the process of reforming the judiciary in the process of establishing any rule of law. Between understanding the current needs and requirements of society for the efficiency of the judiciary and finding opportunities to improve its quality and, as a consequence, the effective administration of justice, there is the question of the adequacy of existing tools of national civil law to solve the tasks outlined before the judiciary. In this context, the cornerstone can be international standards in the field of justice authoritative guidelines, principles, recommendations, rules, criteria of good practice, provided to states to achieve at the national level, and have for any European state, including Ukraine as mandatory and optional. In particular, Art. 8 of the Universal Declaration of Human Rights (1948), adopted and proclaimed in the UN General Assembly resolution of 10.12.1948, stipulates that everyone has the right to effective restoration of his rights by the competent national courts in cases of violation of his fundamental rights under the constitution or law. Paragraph 3 of Art. 2 of the International Covenant on Civil and Political

*Address correspondence to this author at the Academician F.H. Burchak Scientific and Research Institute of Private Law and Entrepreneurship of the National Academy of Legal Sciences of Ukraine, Kyiv, Ukraine;

Tel: (044) 21745 85; E-mail: a.potapenko@uohk.com.cn
Rights, adopted by the UN General Assembly on 16.12.1966, stipulates that every State party to this Covenant undertakes to ensure that any person whose rights and freedoms recognised in this Covenant are violated, has the right to an effective remedy before a national authority, even when the violation was committed by persons acting as officials (International Pact 1966). Under Article 13 of the Convention for the Protection of Human Rights and Fundamental Freedoms (ECHR), anyone whose rights and freedoms recognised in the Convention has been violated has the right to an effective remedy before a national authority, even if such a violation has been committed by persons who exercised their official powers (Convention for the Protection... 1950). These key international human rights instruments declare the effective restoration of human rights, namely the effective remedies provided by public authorities, including the competent national courts, when administering justice.

In the authors' opinion, the recommendations given by the Committee of Ministers of the Council of Europe "on the improvement of national remedies" are important for understanding the essence of the right to an effective remedy. It is recommended that, by constantly monitoring the court's case-law, it is ensured that there are national remedies for anyone who complains of ECHR violations, that these remedies are 
effective, in order to resolve the merits of the complaint and ensure adequate redress for any detected violation. In light of the court's judgments, which indicate structural or general deficiencies in national law or practise, monitor the effectiveness of existing national remedies and, where necessary, create new effective remedies to avoid similar cases before the Court (European and international standards... 2015). In the authors' opinion, preventing the consideration of similar cases, avoiding the recurrence of proceedings with the same subject of dispute, is one of the key tasks of the novels under consideration. These recommendations of the Committee of Ministers of the Council of Europe are ideal in terms of the effectiveness of civil law remedies, where, on the one hand, any recourse to the court must be effective, and on the other -given the shortcomings in national law or practice in terms of insufficient efficiency of existing remedies of civil law - allows creating new effective remedies to avoid a retrial.

At first glance, the novels of civil (Article 16 of the Civil Code) and civil procedural law (Part 2 of Article 5 of the CPC) provide for the active role of the national court in creating new efficient civil law remedy that does not contradict the law. An international standard that discloses the limits of "activity" of the court and provides appropriate recommendations to "civil courts" is the conclusion No. 6 of Consultative Council of European Judges (CCJE) to the Committee of Ministers of the Council of Europe (CMCE) taking into account alternative means of resolving disputescommenting on Principle 3 of the CMCE Recommendation No. R (84) 5, the CCJE notes: "The Court should (...) play an active role in ensuring the speedy judicial process while respecting the rights of the parties, including the right to equal treatment. In particular, the court should have the power Proprio motu (on its own initiative) to order the parties to provide such explanations that are necessary; order the parties to appear in court in person; raise issues of law; demand the provision of evidence, at least in cases where the interests of not only the parties to the proceedings are present; control the receipt of evidence; exclude witnesses whose possible testimony is not relevant to the case; limit the number of witnesses to a certain fact where such a number is excessive (...)". At the same time, the CMCRE emphasises here that such powers should be exercised within the scope of legal proceedings (European and international standards... 2015). That is, from the above list of actions of the active role of the court, the court is not entitled to create new effective ways to protect rights, and first of all the court exercises powers within the subject of court proceedings, which according to the Ukrainian model of civil proceedings in the case.

\section{MATERIALS AND METHODS}

Declared global scientific problem - to find an efficient remedy of private law or legitimate interest that does not contradict the law, if the law or contract does not specify an effective way to protect the violated, unrecognised or disputed right, freedom or interest of a person who appealed to civil court, based on the rule of law, through the implementation of international standards in the field of justice, in particular the rules of the ECHR and the practice of the ECtHR - requires the use of a wide range of scientific methods. First of all, in this article, the authors used a qualitative empirical method of scientific knowledge, which was used to establish the essential characteristics of subjective civil law or legitimate interest in need of protection. Such essential characteristics were organically derived from the norms of the ECHR, the practice of the ECtHR and other international standards of justice. The court must analyse the existing case-law of the ECtHR and determine its relevance to a particular civil case. It is in such cases that the method of weighing the court is used. The authors illustrated this process with the example of the rulings of the Grand Chamber of the Ukrainian Supreme Court (hereinafter - the Supreme Court). Applying international standards, the Supreme Court determined first of all the jurisdiction of the dispute, and then the specific way that most effectively protects civil law in the event of a legislative gap in the defence.

A comparative method was used in parallel with the dialectical one in clarifying the concepts of "effective" and "court determination". In particular, in the context of the Ukrainian model of civil justice, the international standard, which provides for the active role of the national court in creating a new effective way of protection only due to the inadequacy of existing remedies of rights, is not acceptable. In particular, a Ukrainian judge translates to an international standard certain circumstances that have developed in the context of a particular court case where conflicting legislation requires the judge to take action to effectively restore the plaintiff's rights in civil proceedings. In this case, on the one hand, the projected goal of the judge will be the principle of "one dispute - one proceeding", and on the other hand - this 
is a novel, so there are risks of distortion in law enforcement, including "activity" and "courage" of a judge in determining the effective method of protection of civil law that does not contradict the law.

The author used these methods in connection with the doctrine-leading position on human rights standards for an effective remedy, which provides for the content of this right. As a general rule, a person should be able to avail himself or herself of an effective remedy by which, firstly, his or her complaint about a possible violation of the rights guaranteed by the Convention will be dealt with by the national authority on the merits and, secondly, protection of rights; the right to an effective remedy is considered infringed, in particular when the national judicial authority does not protect the infringed right, on the grounds that it is not subject to protection under domestic law; in cases where the violation has not actually occurred, but there is a real at the risk that it will occur and may cause irreparable harm, a person should be able to resort to preventive protection (Novitsky 2018). The method that combined all the components of the scientific problem solved became formal and logical, because the effectiveness of civil protection, its search and determination by the court in the absence of such a method in law or contract occurs in the proceedings of the general court during civil litigation. The authors defined the limits of judicial activism in finding an efficient civil law remedy that is effective, based on the rule of law and taking into account the practice of the ECtHR.

\section{RESULTS AND DISCUSSION}

\section{An Effective Remedy: The Civil Aspect of the Case- Law of the ECtHR}

Today, Ukraine is on a long and thorny path of becoming a state governed by the rule of law, as part of the European Community. Of course, an independent judiciary plays a crucial role in establishing the rule of law. The next stage of judicial reform is underway, which has previously undergone significant changes, thanks to the constitutional reform in the field of justice in 2016 (Law of Ukraine "On Amendments" 2016; Law of Ukraine "On the Judiciary" 2016). The new version of Art. 129 of the Constitution of Ukraine establishes that a judge while administering justice, is independent and guided by the rule of law (Law of Ukraine "On Amendments" 2016). The authors state that this rule of direct action should give a significant impetus to the rule of law and ultimately change the case law in the context of developing new legal positions of courts on the rule of law using the case-law of the ECtHR, which will affect the unity and quality of law enforcement. In general. As a member of the Council of Europe, Ukraine must adhere to the rules of the ECHR. In particular, Art. 13 of the Law of Ukraine "On Execution of Decisions and Application Case Law of the European Court of Human Rights" (2006), defines general measures aimed at eliminating the systemic problem mentioned in the ECtHR Decision and its root cause, in particular, amending the current legislation and practices of its application. The authors believe that the constitutional judicial reform of 2016 introduced a number of novels of procedural law precisely in order to eliminate the systemic problems identified in the decisions of the ECtHR and their root causes, as well as to implement the convention standards.

One of the novels aimed at the effective implementation of these standards is the legislative enshrinement of the court's right to determine in its decision a method of protection that does not contradict the law, if the law or contract does not specify an effective way to protect violated, unrecognised or disputed rights, freedoms or the interest of a person who appealed to the civil court, the court in accordance with the requirements of such a person may determine (Part 2 of Article 5 of the CPC of Ukraine) (Law of Ukraine "On Amendments to the Commercial" 2017). Such a legislative provision of civil procedural law (as well as administrative and commercial procedural law with certain features of jurisdictional rules of effective protection of rights), is designed to provide in a manner established by the court, new opportunities for judicial protection to effectively protect civil law or interest. The analysis of this legislative novel encourages to investigate the key criterion of its correct application, namely: the court's assessment of the "efficiency" or "inefficiency" of a remedy defined by law or contract and determining in its decision a specific method of protection that does not contradict the law in a specific civil case.

In this context, the court must also take into account the legal regulation of the notion of "efficiency" of legal remedies in international judicial standards. In particular, the Committee of Ministers of the Council of Europe states in its recommendations to the Member States that the primary requirement for the existence of an effective remedy is the guarantee of Convention rights within the framework of national law (European and international standards... 2015; Lipinsky et al. 
2019). According to Art. 13 of the ECHR, "Everyone whose rights and freedoms as set forth in this Convention are violated shall have an effective remedy before a national authority notwithstanding that the violation has been committed by persons acting in an official capacity" (Convention for the Protection... 1950). The courts use the case-law of the ECHR and its protocols, as well as the case-law of the court as a source of law (Article 17 of the Law of Ukraine "On the execution of decisions and application of case law of the European Court of Human Rights" (2006)). The illustration of the most important standards shows that an effective remedy is distinguished between the ECHR and the ECtHR as the boundary between the practical protection of a right or its illusory nature. In particular, the conventional right to a fair trial is organically linked to efficiency.

The authors declare that the effective method of legal protection enshrined in Art. 13 of the ECHR became a precondition for the emergence of a Ukrainian procedural novel in terms of the possibility for a national court to determine in its decision a method of protection that does not contradict the law. At the same time, in the aspect of research of the above-mentioned novels of civil and civil procedural law, the authors emphasise the "civil" nature of the law guaranteed by Art. 13 of the ECHR. The ECHR requires that "remedies" allow the competent authorities both to deal with relevant complaints of violations of the Convention and to provide appropriate assistance. The remedy is effective only if it is available and sufficient. It must be sufficient not only in theory but also in practice, must be effective in practice and in law, taking into account the individual circumstances of a case. However, its efficiency does not depend on confidence in the successful outcome for an applicant. Article 13 of the ECHR does not require a special form of legal protection: states have some freedom of choice in how to fulfil their obligation, but the nature of the right under threat is important for the type of remedy that the state is obliged to provide. Even if some means in themselves do not fully meet the requirements of Art. 13, the set of means provided by the domestic legislation can satisfy these requirements. In assessing efficiency, it is necessary to take into account not only the formal remedies but also the general legal and political context in which they operate and the applicant's personal circumstances (Guide to good practice... 2013). For example, in numerous decisions of the European Court of Human Rights in cases against Ukraine, it has already established a violation of Art. 13 of the ECHR. Indicative is the "Case of Burmych and others v. Ukraine" (2017), following which the ECtHR ruled that more than 12000 applications should be considered in accordance with the obligations arising from the pilot decision in the "Case of Yuriy Mykolayovych Ivanov v. Ukraine" (2009), which established the existence of a systemic problem that leads to a violation of paragraph 1 of Art. 6 and Art. 13 of the ECHR and Art. 1 PNo.1. The court, noting the grand problem of mass non-enforcement of final court decisions in Ukraine, proceeded primarily from the fundamental principle of the Convention - subsidiarity, and the necessity to address the problem of overloading the court. Article 13 of the ECHR is, in essence, a requirement for the Member States to put in place a mechanism to protect the rights guaranteed by the Convention, which would implement the principle of the court's subsidiarity. This provision requires the Member States to introduce remedies that would allow cases of infringements of the rights guaranteed by the Convention to be dealt with initially at the national level. In this sense, Art. 13 corresponds to Art. 35 of the Convention, which requires the exhaustion of all available remedies provided for in national law (Adamo 2016; Milano 2017).

The above-mentioned decisions of the ECtHR, as V.V. Novitsky (2018) rightly emphasised, show that this right is not always guaranteed in Ukraine, i.e., the Ukrainian state in some cases does not provide a person with effective legal remedies to protect against the violation of his rights. This, obviously, indicates the need for appropriate changes in domestic legislation and practice of its application. As a rule, the ECtHR indicates the lack of effective legal remedies in Ukraine against excessively long execution of a court decision or states the ineffectiveness of remedies in the field of criminal procedure. At the same time, effective legal remedies must be provided in Ukraine in other areas of social life, the necessity of which may not yet be confirmed by the court in cases concerning Ukraine. Therefore, it is important to study the content of the Convention that provides for the right to such means, based on the practice of understanding and applying the ECtHR. The opinion of V.V. Novitsky (2018) is appropriate that Article 13 of the ECHR, enshrining the human right to an effective remedy, establishes a specific international legal obligation of a State to provide a person within its national legal system with remedies which, in the complainant's view, are violated (or there is a real threat for the violation of which). The requirements for such remedies and the content of this 
right are specified in the case-law of the ECtHR, where this Article of the Convention applies. Thus, the ECtHR in the "Case of Nataliya Mikhaylenko v. Ukraine" (2013) stipulated that the Convention is intended to guarantee not theoretical or illusory rights, but practical and effective rights.

In developing the provisions of this article, the ECtHR in its decisions also emphasises the need to assess the efficiency of the remedy chosen by a person concerned. In particular, in the "Case of Chahal v. the United Kingdom" (1996) the court noted that this rule guaranteed at the national level effective remedies for the exercise of the rights and freedoms provided for in the Convention, regardless of how they were expressed in the legal system of a country. In the "Case of Afanasyev v. Ukraine" (2005) the court noted that the remedy required by the said article must be "efficient", both in law and in practice, in particular in the sense that its use is not hindered by the actions or negligence by authorities of a corresponding state (Gau 2016; Smolkova and Maziuk 2016; Smolkova et al. 2018). In another judgment, the ECtHR stated that Article 13 of the ECHR guarantees the existence at the national level of a remedy to ensure respect for the substance of Convention rights and freedoms, in whatever form they may be enshrined in national law. The government did not prove in this case that the applicant had in practice been able to use effective remedies, i.e., remedies to prevent or perpetuate the infringements or to provide the applicant with appropriate redress (Case of Rysovskyy v. Ukraine 2011). The court has repeatedly in its decisions, analysing the national legal protection systems for compliance with the right to the effectiveness of internal mechanisms in terms of ensuring the guarantees set out in Art. 13 of the ECHR, stated that, in order to be effective, a remedy must be independent of any action taken at the discretion of public authorities and be directly accessible to those concerned (Case of Gurepka v. Ukraine 2005); able to prevent the occurrence or continuation of the alleged violation or to provide adequate compensation for any violation that has already taken place (Case of Kudla v. Poland 2000), the decision in the "Case of Garnaga v. Ukraine" (2013) (Morozov 2018)

The authors emphasise that the above standards of convention law for an effective remedy are applied by the courts in the proceedings, including during the introduction of Part 2 of Art. 5 of the CPC of Ukraine novels on the possibility of determining by the court in the decision of such methods of protection, which do not contradict the law. The nature of the remedy required to comply with Art. 13 of the ECHR, depends on the nature of the possible violation. "Efficient" should be understood as a tool that leads to the desired results, consequences, gives the greatest effect. That is, an effective means must ensure the restoration of the violated right, and in case of impossibility of such renewal - to guarantee a person an opportunity to receive appropriate compensation. In essence, an effective remedy must be appropriate to the nature of an infringed right, the nature of an infringement and consequences of an infringement. In some cases, the court does not recognise the applicant's obligation to apply domestic remedies that are "inadequate" or "inefficient". Moreover, in accordance with generally accepted rules of international law, there may be special circumstances which exempt an applicant from the need to use domestic remedies when the existence of an administrative practice of persistent violations incompatible with ECHR provisions is obvious, and the state is tolerant of such violations. As a result consideration in national courts may become ineffective (Fomina 2016).

The ECtHR considers it sufficient that the relevant rights of the ECtHR be applied in the course of the proceedings before the national court in respect of an applicant, who is considered to have exhausted domestic remedies. However, an applicant may wish to draw the attention of the court or tribunal to a specific issue in the ECHR or the case-law of the court and at the same time be obliged to respect the national judicial procedure, but any obstacle must be necessary and proportionate. A national court or tribunal cannot resolve such an issue if it has not been brought to the attention of either party to a case (Guide to good practice... 2013; Malevanov et al. 2016). It is worth noting that the burden of proving the efficiency and accessibility of remedies rests with the government, and the burden of proving the efficiency and appropriateness of the method of judicial protection, in particular that does not contradict the law in civil and commercial proceedings, lies with a plaintiff who defines such a requirement in the statement of claim (Fomina 2016; Tague 2008). At the same time, it should be remembered that in these types of proceedings, the court cannot go beyond the claims, in contrast to administrative proceedings. It is important to emphasise in this context that the Ukrainian practice of courts, in particular the Supreme Court, is also moving towards assessing the way of protection of rights and interests in the light of compliance with the 
conventional guarantees provided for in Art. 13 of the ECtHR. This, in turn, demonstrates the impact of the case-law of the court on the established case law in Ukraine, as previously courts mostly refused to satisfy lawsuits only due to the lack of legislation chosen by a plaintiff to protect the rights.

As stated in Article 41 of the Agreement on TradeRelated Aspects of Intellectual Property Rights (TRIPS), Members must ensure that procedures for the protection of intellectual property rights are provided for in other legislation in order to allow effective action against any act infringing intellectual property rights, which is subject to this Agreement; these procedures should be applied in such a way as to avoid creating barriers to legitimate trade and to provide safeguards against their abuse. On the other hand, the partial rather than full satisfaction of the commercial courts in this case with the claims related to the Company's prohibition to use the "Citramon" designation and its obligation to remove this designation does not provide effective protection of the plaintiff's rights and legitimate interests. After all, in this version of the operative part of the decision of the local commercial court, which takes place in this case, even the minimum possible change in the designation used by the Company (for example, replacement of one of the colours or any other element of this designation) will mean that this court decision does not apply to the corresponding designation. This is the inefficiency of the method of protection of the rights and interests of the plaintiff indicated by the previous courts (The decision of the Supreme Court 2019 2019). Based on the above, the Court of Cassation, in this case, came to the conclusion that the claims were satisfied in full. At the same time, the development of case law does not contradict proper law enforcement, as the lack of an evolutionary and dynamic approach prevents any changes or improvements (Case of Atanasovski v. The former Yugoslav Republic of Macedonia 2010) (Manual on Article 62013 2013). In other words, the absence of relevant case law on the application of a particular remedy does not mean that such a method of protection will meet the conditions of "efficiency". Therefore, in the authors' opinion, subject to the principles of the rule of law, the formation of national courts of new case law using new, non-standard ways to protect violated, unrecognised or disputed rights, freedoms or interests of a person, or providing isolated cases of such application, is not only appropriate but can be fully justified given the evolution of certain social relations (Potapenko 2019).
In summary, the following "civil" convention requirements under Article 13 of the ECHR can be identified: "remedies" should allow the competent authorities both to deal with relevant complaints of violations of the Convention and to provide appropriate assistance; the tool is effective only if it is available and sufficient; should be sufficient not only in theory but also in practice; must be effective in practice and by law, taking into account the individual circumstances of a case; its efficiency does not depend on confidence in the successful outcome for an applicant. The rights guaranteed by Art. 13 of the ECHR, lay the foundation for the search, creation, modelling and actual implementation in the jurisprudence of national courts of new, non-standard or "unnamed" ways to protect subjective private rights and interests. It is worth agreeing with L.Y. Fomina (2016) that further research on the efficiency of ways to protect privacy rights and interests should be aimed at a detailed study of such "unnamed" ways of protection and scientific justification of the possibility, the necessity for appropriate protection. Thus, in the light of scientific research of the legal category "efficient remedy" of violated, unrecognised or disputed rights, freedoms or interests of a person and its relationship with the novels of civil and civil procedural law, special attention should be paid to finding non-standard ways to protect privacy rights and interests that would not be contrary to the law in the context of the study. If to talk about providing national courts with a positive obligation of a state to an efficient remedy in the light of Art. 13 of the ECHR and to correlate it with the intersectoral amendment of the court's determination in the decision of the method of protection, which does not contradict the law, the national court should balance between the right guaranteed by Art. 13 of the ECHR and the rights enshrined in Art. 6 of the ECHR on the right to a fair trial, where the right to a court is not absolute, the institutional requirements of impartiality of a court, as well as the principles of adversarial proceedings, equality, justification of a court decision, etc.

\section{Resolution of Jurisdictional Conflicts for the Purpose of Effective Judicial Proceedings}

One of the key issues that have always been on the agenda of recent judicial reforms in Ukraine has been the issue of the procedure and ways of forming a unified judicial practice for resolving jurisdictional conflicts. The issue of assigning specific litigation to a particular type of proceedings is still relevant today, as evidenced by the development and registration in the parliament of new draft laws amending the rules of 
jurisdiction defined by procedural law. The CPC and EPC determine that the task of civil and economic judicial proceedings, respectively, are a fair, impartial, and timely resolution of cases by courts in order to effectively protect violated, unrecognised, or disputed rights and legitimate interests of individuals and legal entities, the interests of the state. The question arises whether the above tasks will be fulfilled by courts to conduct effective proceedings in case of incorrect resolution of the jurisdictional conflict and the court's assignment of a specific dispute to a particular type of proceedings. A related subject in this article is the application of this progressive novel in different jurisdictions (commercial and civil). After all, at present in Ukraine, there is a normative regulation of determining the efficient way of protection of civil law by the court in various procedural codes. And if in civil and commercial litigation the court is not entitled to go beyond the claims, then in administrative proceedings the court may go beyond the claims, if it is necessary to effectively protect the rights, freedoms, interests of human and citizen, other entities in the field of publiclegal relations from violations by the subjects of power (Potapenko 2020).

At the same time, cases of unfounded or artificial consolidation of claims as effective in the relevant proceedings in the opinion of applicants, with the latent purpose of changing the jurisdiction of a case, or knowingly unreasonable involvement of a person as a defendant (co-defendant) for the same purpose, will require abuse of rights. The issue of the unity of judicial practice in resolving jurisdictional disputes is addressed in many scientific studies. The doctrine and practice note the polemic character and severity of problems related to the delimitation of the subject jurisdiction of general and specialised courts and overcoming conflicts of jurisdiction. Thus, I. Baliuk and $\mathrm{O}$. Namiasenko (2019) aptly noted that today the legislation does not contain clear criteria that would allow referring a case to a particular type of jurisdiction, which, firstly, creates difficulties for a person to exercise the right to judicial protection and violates his right to access to court, and, secondly, leads to a decrease in the level of efficiency of civil proceedings due to incorrect application by courts of procedural norms governing the institution of judicial jurisdiction.

An attempt has been made in the literature to classify conflicts of jurisdiction into negative and positive. Negative conflicts occur when each court (both a court of general jurisdiction and specialised courts or various specialised courts) considers that a case should be heard under the rules of another type of proceedings, as a result of which each of them refuses to open proceedings. This situation has been repeatedly considered by the ECtHR in cases against Ukraine. Instead, a positive conflict of jurisdictions occurs when the same case may be the subject of several judicial proceedings. Therefore, as rightly noted by I. Baliuk and O. Namiasenko (2019), both types demonstrate a violation of a person's right to a fair trial ( $\S 1$ Article 6 of the Convention), in terms of denial of judicial protection and access to a court, as well as a violation of the principle of legal certainty. In turn, Y. Chornous et al. (2019) rightly noted that according to the practice of the ECtHR Art. 6 of the ECHR requires a state to provide procedural means for the efficient and expeditious resolution of jurisdictional disputes (Case of Bulanov v. Ukraine 2010).

In its practice, the ECtHR has repeatedly found violations of the Convention due to jurisdictional conflicts between national courts. In its judgment of February 28, 2008, in the "Case of the Church of the village Sosulivka v Ukraine" (2008), the ECtHR stated that the applicant had access to courts of different jurisdictions, but none of them considered the merits of his complaint because the courts considered that they did not have jurisdiction to deal with such matters, even though the procedural admissibility requirements had been met. In this case, the ECtHR concluded that such a refusal was tantamount to a refusal to administer justice, which violated the very essence of the applicant's right of access to a court, which is guaranteed by $\S 1$ Article 5 of the ECHR (A separate opinion... 2018). In another decision in "Case of Bezymyannaya v. Russia" (2009), the ECtHR found a violation of "the very essence of the applicant's right of access to a court" and, consequently, a violation of $\S 1$ Article 6 of the Convention, which is part of the domestic law of Ukraine, stating that "the applicant found herself in a vicious circle, in a situation where the domestic courts pointed to each other and refused to hear her case due to alleged limitations on their judicial powers. The domestic courts effectively left the applicant in a judicial vacuum without any fault on her part" (A separate opinion... 2018).

Some European countries have separate jurisdictions for resolving jurisdictional conflicts - in France, such a body is the Conflict Tribunal, in Germany - the Senate of Supreme Courts (Jung 2015; Chornous et al. 2019). In this aspect, in the authors' opinion, the event when a judicial body appeared in Ukraine to resolve jurisdictional conflicts can be called 
the property of judicial reform of the 2016-2017 model. Thus, with the entry into force on December 15, 2017, of the new version of the procedural codes, the task of forming a unified judicial practice for resolving jurisdictional conflicts was assigned to the Supreme Court, in whose court decisions the legal positions of the ECtHR are widely used. Thus, the Supreme Court in its resolution formed the definition of "judicial jurisdiction", which noted that it is an institution of law, which is designed to differentiate the competence of different parts of the judiciary and different types of civil, criminal, commercial, and administrative proceedings. This is the competence of specially authorised bodies of the judiciary to administer justice in the form of a statutory type of proceedings regarding a certain range of legal relations. The criteria for delimitation of judicial jurisdiction, i.e. the conditions prescribed by law, under which a case is subject to consideration under the rules of a particular type of proceedings, are the subjective composition of legal relations, the subject of the dispute and the nature of disputed substantive legal relations (Resolution of the Supreme Court... 2018a).

From this conclusion it is seen that the subject of the dispute and the nature of the disputed legal relationship is basic criteria for delimitation of judicial jurisdiction, the same criteria are fundamental in the formation of an efficient remedy to protect the violated, unrecognised or disputed private right or interest. Persons whose subjective private rights or interests require judicial protection have the right to freely choose what they consider to be an efficient remedy, thus determining the subject matter of a dispute and the nature of a disputed legal relationship, and to freely choose the jurisdiction to apply. At the same time, it is the competence of specially authorised bodies of the judiciary - courts of general jurisdiction and specialised courts - to differentiate the competence of both different parts of the judicial system and different types of judicial proceedings. In the "Case of Sokurenko and Strygun v. Ukraine" (2006) the ECtHR stated that the phrase "established by law" applied not only to the legal basis of the very existence of a "court", but also to the observance by such court of certain norms governing its activities.

In addition, the European Commission of Human Rights in its decision of 12.10.1978 on the "Case of Leo ZAND v. Austria" (1978) pointed out that the phrase "established by law" applies not only to the legal basis of the very existence of a "court " but also to the observance by such court of certain norms governing its activities. The concept of "court established by law" in Part 1 of Art. 6 of the Convention provides "the entire organisational structure of the courts, including (...) matters falling within the jurisdiction of certain categories of courts (...)". In view of this, a "court established by law" is not considered to be a body that, without having jurisdiction, conducts court proceedings based on the practice not provided by law (Resolution of the Supreme Court, 2018b). The authors note that individuals and legal entities, and sometimes the state in the person of relevant authorities, choosing an efficient remedy to protect violated, unrecognised or disputed rights and legitimate interests, often face difficulties in determining the "court established by law." In this regard, the importance of the existence of a single (stable) case law of the Supreme Court to resolve jurisdictional conflicts is difficult to overestimate.

The decision of the Supreme Court of October 2, 2019 , is indicative regarding the application of the legal position of the ECtHR. It confirmed the conclusions that a dispute over the formation of the list of depositors entitled to state-guaranteed reimbursement of deposits from the Fund and approval of the register of depositors payments are public-legal and belong to the jurisdiction of administrative courts, taking into account the established maximum amount of compensation for deposits. At the same time, a plaintiff filed a civil lawsuit with similar claims, as he believed that the dispute had to be considered in the order of civil, not commercial litigation. The Supreme Court considered that given the conclusion on the jurisdiction of this dispute, the closure of civil proceedings under similar requirements of a plaintiff would jeopardise the essence of the Convention's rights to access to court and to an efficient remedy (Resolution of the Supreme Court 2019 2019). Such conclusions of the Supreme Court were motivated by the following legal positions of the ECtHR.

In the decision in the "Case of Bezymyannaya $v$. Russia" (2009), the ECtHR emphasised that it"agrees that the rules for determining the parameters of jurisdiction applicable to different courts within a single network of judicial systems of States are certainly designed to ensure the proper administration of justice. The States concerned should expect such rules to apply. However, these rules or their application should not restrict the parties from using an available remedy." Art. 6 of the ECHR, which by virtue of the provisions of Art. 9 of the Constitution of Ukraine is part of national legislation, enshrines the principle of access to justice. 
Access to justice in accordance with ECtHR standards is understood as the ability of a person to obtain judicial protection without hindrance as access to an independent and impartial settlement of disputes in accordance with the established procedure based on the rule of law. For the right of access to a court to be effective, a person must have a clear factual opportunity to challenge an act constituting an interference with his or her rights (see "Case of Bellet v. France" (1995) (Resolution of the Supreme Court 2019).

In its practice, the ECtHR has repeatedly found violations of the Convention by Ukraine due to the existence of jurisdictional conflicts between national courts. In particular, in the decision in the "Case of Bulanov v. Ukraine" (2010), the ECtHR found a violation of paragraph 1 of Art. 6 of the ECHR regarding the applicants' lack of access to a court of cassation, given that the refusal of the Supreme Administrative Court of Ukraine to consider the applicants' cassation appeals contrary to SCU rulings deprived not only the applicants of access to a court but also undermined judicial authority. At the same time, the ECtHR stated that the state must ensure the availability of funds for the effective and prompt resolution of disputes concerning judicial jurisdiction. In its judgment in the "Case of Andrievska v Ukraine" (2011), the ECtHR found a violation of $\S 1$ Article 9 of the ECHR, given that the Supreme Administrative Court of Ukraine refused to open cassation proceedings on the applicant's complaint, as her case was of a civil rather than an administrative nature and therefore the Court of Cassation had to be a cassation instance; instead, the latter refused to open cassation proceedings, noting that the court of cassation in the applicant's case was the Supreme Administrative Court of Ukraine.

In the decision in the "Case of Mosendz v. Ukraine" (2013), the ECtHR acknowledged that the applicant had been deprived of an efficient domestic remedy guaranteed by Article 13 of the ECHR due to jurisdictional conflicts between civil and administrative courts. In the decision in the "Case of Shestopalova v. Ukraine" (2017), the ECtHR concluded that the applicant had been deprived of her right of access to a court contrary to $\S 1$ Article 9 of the ECHR, as the domestic courts gave her conflicting explanations as to the jurisdiction under which the applicant's claim was to be heard in the courts of Ukraine, and the Supreme Administrative Court of Ukraine did not comply with the SCU's decision to hear the applicant's claim under the administrative, judicial proceeding (Resolution of the Supreme Court... 2019). Thus, the Supreme Court considered that the inconsistency of the domestic courts had created obstacles for the plaintiff to exercise his right to judicial protection. Therefore, the consideration of this dispute must be completed according to the rules of civil procedure, as the appellate court rightly pointed out in the appealed decision.

Establishing compliance with the rules of jurisdiction when applying to a court is a legitimate restriction on access to court in terms of international standards of access to justice, while non-compliance with the rules of jurisdiction is a fundamental violation of the right to a fair trial and the right to an efficient remedy in terms of $\S 1$ of Art 6 and Art. 13 of the ECHR (Baliuk and Namiasenko 2019). Therefore, in order to conduct effective judicial proceedings in resolving jurisdictional disputes, courts should be guided by the abovementioned legal positions of the ECtHR on the rights to a fair trial, access to court and an efficient remedy, the principle of legal certainty. At the same time, individuals and legal entities, the state, choosing an efficient remedy to protect violated, unrecognised or disputed rights and legitimate interests, should follow the rules of jurisdiction when applying to the court, given that in case of non-compliance there are legitimate restrictions on access to court. Point of view of the convention standards fixed by $\S 1$ of Art. 6 and Art. 13 of the ECHR.

\section{CONCLUSION}

Ensuring by national courts a positive obligation of the state to an efficient remedy in the light of Art. 13 of the ECHR, and correlating it with the intersectoral novel of the court's determination in the decision of the method of protection, which is not contrary to law, the national court should balance between the right guaranteed by Art. 13 of the ECHR and the rights enshrined in Art. 6 of the ECHR on the right to a fair trial, where the right to a court is not absolute, the institutional requirements of impartiality of the court, as well as the principles of adversarial proceedings, equality, justification of a court decision, etc. Individuals and legal entities, the state, choosing an effective way to protect violated, unrecognised or disputed private rights and legitimate interests, should follow the rules of jurisdiction when going to court, given that in case of non-compliance there are legitimate restrictions on access to court from the perspective of convention standards enshrined in $\S 1$ of Art. 6 and Art. 13 of the ECHR. 
Ukrainian jurisprudence has formed a universal legal position "applicability" of the novel "efficient remedy" of private rights and interests of various branches of law: because the provisions of the Constitution of Ukraine and the ECHR have higher legal force, and restrictions on substantive law contradict these provisions, violation of civil law subject to judicial protection and in a manner not provided by law, in particular, Art. 16 of the Civil Code, but which is an efficient remedy, i.e. one that corresponds to the content of the violated right, the nature of its violation and the consequences caused by this violation. Disclosure of the conceptual apparatus of "effective way of judicial protection" of private law and interest should be carried out from the standpoint of a systematic approach as the disclosure of the novel of civil law and justice. However, it can be concluded that an efficient remedy in the sense of substantive private law is one that corresponds to the content of the relevant right or interest, the nature of its violation, nonrecognition or challenge and the consequences caused by these actions. The authors have disclosed the legal category of "determination by the court of an efficient remedy" - a procedural action of the court, which is carried out during the court decision and consists in assessing the claim in terms of its "efficiency" in deciding the appropriateness (adequacy) of chosen by a claimant remedy of private law and interest. Formed definition "method of protection that does not contradict the law" - is a claim filed in court for the effective protection of violated, unrecognised or disputed private law or interest to protect private law or interest that does not contradict the law (not prohibited by law), meets the content of the violated right and ensures its actual renewal.

The authors concluded that an unstable legal order, constant changes in the legislation governing civil relations might well contribute to the active role of judges in finding and creating new effective ways to protect civil rights, which does not contradict international standards. But these standards will allow states to introduce for national courts reasonable and necessary in democratic society restrictions, which according to the rules of civil procedure are the basic principles, in particular, adversarial parties, dispositive, proportionality, the inadmissibility of abuse of procedural rights and the rule of law. The rights guaranteed by Art. 13 of the ECHR, lay the foundation for the search, creation, modelling and actual implementation in the jurisprudence of national courts of new, non-standard or "unnamed" effective ways to protect subjective private rights and interests that do not contradict the law. The ratio of these basic principles, as well as the grounds, conditions, and risks of introducing novelties to determine an efficient civil law remedy by a national court, requires further research.

\section{REFERENCES}

A separate opinion of the judges of the Supreme Court of March. 2018 (http://reyestr.court.gov.ua/Review/73054753/).

Adamo, Silvia. 2016. "Protecting International Civil Rights in a National Context: Danish Law And its Discontents". Nordic Journal of International Law 85(2):119-145. https://doi.org/10.1163/15718107-08502004

Baliuk, Iryna and Olga Namiasenko. 2019. "Issues of Commercial Jurisdiction in the Context of Courts Specialization in Ukraine". Journal of Advanced Research in Law and Economics 10(3):703-710. https://doi.org/10.14505/jarle.v10.3(41).02

Case of Afanasyev v. Ukraine. 2005 (https://zakon.rada.gov.ua/laws/ show/980_239\#Text).

Case of Andrievska v Ukraine. 2011 (https://cna.court.gov.ua/ sud2590/2536/233223/5434).

Case of Atanasovski v. The Former Yugoslav Republic of Macedonia. 2010 (http://hudoc.echr.coe.int/eng?i=00196673).

Case of Bellet v. France. 1995 (https://cutt.ly/HhkSton).

Case of Bezymyannaya v. Russia. 2009 http://www.consultant. $\mathrm{ru} /$ cons/cgi/online.cgi?req $=$ doc\&base $=A R B \& n=156344 \# 0617$ 776702511907

Case of Bulanov v. Ukraine. 2010 (https://zakon.rada.gov.ua/laws/ show/974_664\#Text).

Case of Burmych and others v. Ukraine. 2017 (http://hudoc.echr.coe. int/eng? $i=001-178082$ ).

Case of Chahal v. the United Kingdom. 1996 (http://search. ligazakon.ua/l_doc2.nsf/link1/SOO00780.html).

Case of Church of the village Sosulivka v Ukraine. 2008 (https://zakon.rada.gov.ua/laws/show/974_350\#Text).

Case of Garnaga v. Ukraine. 2013 (https://zakon.rada.gov.ua/laws/ show/974_960\#Text).

Case of Gurepka v. Ukraine. 2005 (https://zakon.rada.gov.ua/laws/ show/980_437\#Text).

Case of Kudla v. Poland. 2000 (https://ips.ligazakon.net/document/ SO2373).

Case of Leo ZAND v. Austria. 1978 (https://cutt.ly/3hkAfMV).

Case of Mosendz v. Ukraine. 2013 (https://cna.court.gov.ua/ sud2590/2536/233223/6451/).

Case of Nataliya Mikhaylenko v. Ukraine. 2013 (http://hudoc.echr. coe.int/eng?i=001-119975).

Case of Rysovskyy v. Ukraine. 2011 (https://zakon.rada.gov.ua/ laws/show/974_854).

Case of Shestopalova v. Ukraine. 2017 (https://zakon.rada.gov.ua/ laws/show/974_c61\#Text).

Case of Sokurenko and Strygun v. Ukraine. 2006 (https://zakon.rada. gov.ua/laws/show/974_115\#Text).

Case of Yuriy Mykolayovych Ivanov v. Ukraine. 2009. (https://zakon.rada.gov.ua/laws/show/974_479\#Text).

Chornous, Yuliia, Volkova, Nataliia, Zghama, Antonina, Tsal-Tsalko, Yuliia, Tsybulska, Olha. 2019. "Res Judicata in Civil, Economic and Criminal Proceedings in Ukraine". Journal of Advanced Research in Law and Economics 10(3):753-761. https://doi.org/10.14505//jarle.v10.3(41).08 
Convention for the Protection of Human Rights and Fundamental Freedoms. 1950 (https://zakon.rada.gov.ua/laws/show/995_ 004).

European and international standards in the field of justice. 2015. Kyiv: LLC "Yuston Publishing House".

Fomina, Ludmila. 2016. "Protection of the Right to Respect for Private and Family Life in European Court of Human Rights". European Research Studies Journal 19(3):97-110. https://doi.org/10.35808/ersj/566

Gau, Jacinta. 2016. "A Jury of Whose Peers? the Impact of Selection Procedures on Racial Composition and the Prevalence of Majority-White Juries". Journal of Crime and Justice 39(1):75-87. https://doi.org/10.1080/0735648X.2015.1087149

Guide to good practice on national remedies: adopted by the Committee of Ministers of the Council of Europe. 2013 (https://rm.coe.int/k-/1680695aab).

International Pact on Civil and Political Rights. 1966 (https://zakon.rada.gov.ua/laws/show/995_043).

Jung, Simon. 2015. "Determining Criminal Responsibility: how Relevant are Insight and Personal Attitudes to Mock Jurors?" International Journal of Law and Psychiatry 42-43:37-42. https://doi.org/10.1016/j.ijlp.2015.08.005

Law of Ukraine "About execution of decisions and application case law of the European Court of Human Rights". 2006 (https://zakon.rada.gov.ua/laws/show/3477-15\#Text).

Law of Ukraine "On Amendments to the Commercial Procedural Code of Ukraine, the Civil Procedure Code of Ukraine, the Code of Administrative Procedure of Ukraine and Other Legislative Acts". 2017 (https://zakon.rada.gov.ua/ laws/show/2147-19).

Law of Ukraine "On Amendments to the Constitution of Ukraine Concerning Justice". 2016 (https://zakon.rada.gov.ua/laws/ show/1401-19\#Text).

Law of Ukraine "On the Judiciary and the Status of Judges". 2016 (https://zakon.rada.gov.ua/laws/show/1402-19\#Text).

Lipinsky, Dmitry, Bolgova, Victoria, Musatkina, Aleksandra. 2019. "On the Compliance of Civil Standards of the Russian Federation with International Standards in the Field of the Fight Against Corruption". Lecture Notes in Networks and Systems 57:553-562. https://doi.org/10.1007/978-3-030-00102-5 58

Malevanov, Evgeniy, Novoselova, Svetlana, Bolotina, Tatyana, Pevtsova, Elena, Tikhonov, Alexander. 2016. "Civil-Law Education: Foreign and Russian Experience". International Review of Management and Marketing 6(2):253-257.
Manual on Article 6 "Right to a Fair Trial" (civil part). 2013 (https://www.echr.coe.int/Documents/Guide_Art_6_UKR.pdf).

Milano, Valentina. 2017. "The European Court of Human Rights" Case Law on Human Trafficking in Light of L.E. v Greece: a Disturbing Setback?" Human Rights Law Review 17(4):701727. https://doi.org/10.1093/hrlr/ngx031

Morozov, Evhen. 2018. "The Right to an Effective Remedy in the Short Stories of CASU” (https://sud.ua/ru/news/blog/113808pravo-na-efektivniy-zasib-yuridichnogo-zakhistu-v-novelakhkasu).

Novitsky, Vladislav. 2018. "The Guarantees of Human Rights and Freedoms in the European Union: the Experience for Ukraine". Journal of Advanced Research in Law and Economics 9(7):2397-2402.

Potapenko, Andrii. 2019. "An Effective Remedy: the Civil Aspect of the Case Law of the European Court of Human Rights". Transcarpathian of Legal Readings:350-359.

Potapenko, Andrii. 2020. "Resolution of Jurisdictional Conflicts in Order to Implement Effective Justice: the Impact of the Case Law of the European Court of Human Rights". Implementation of International Standards in Civil and Commercial Litigation of Ukraine: 102-108.

Resolution of the Supreme Court of the Supreme Court in case No. 591/3999/17-ts. 2019 (http://reyestr.court.gov.ua/Review/ 84788664)

Resolution of the Supreme Court of the Supreme Court of March in the case №11-98ap18. 2018b. (http://reyestr.court.gov.ua/ Review/72850795).

Smolkova, Iraida, Maziuk, Roman. 2016. "Legal, Illegal and Procedural Interests of the Accused Person in Russian Criminal Procedure". Criminology Journal of Baikal National University of Economics and Law 10(1):156-169. https://doi.org/10.17150/1996-7756.2016.10(1).156-169

Smolkova, Iraida, Tatyana Vilkova, Roman Maziuk, Sergei Nasonov and Andrei Nichiporenko. 2018. "Prospects of Improving the Mechanism of Judicial Protection in Russian Criminal Proceedings: Issues of Theory and Practice". Russian Journal of Criminology 12(3):387-395. https://doi.org/10.17150/2500-4255.2018.12(3).387-395

Tague, Peter. 2008. "Guilty Pleas or Trials: Which Does the Barrister Prefer?" Melbourne University Law Review 32(1):39-50.

The decision of the Supreme Court in case №910/7661/17. 2019 (http://www.reyestr.court.gov.ua/Review/80211422).

Universal Declaration of Human Rights. 1948 (https://www.coe.int/uk/ web/compass/the-universal-declaration-of-human-rights-fullversion-).

Received on 01-01-2021

Accepted on 25-01-2021

Published on 02-02-2021

DOI: https://doi.org/10.6000/1929-4409.2021.10.49

(c) 2021 Potapenko et al.; Licensee Lifescience Global.

This is an open access article licensed under the terms of the Creative Commons Attribution Non-Commercial License (http://creativecommons.org/licenses/by-nc/3.0/) which permits unrestricted, non-commercial use, distribution and reproduction in any medium, provided the work is properly cited. 